\title{
Does tertiary vocational education beat academic education? A matching analysis of young men's earnings developments
}

\author{
Veronika Lukesch ${ }^{1}$ and Thomas Zwick ${ }^{1,2,3^{*}}$ (i)
}

\author{
${ }^{*}$ Correspondence: \\ thomas. \\ zwick@uni-wuerzburg.de \\ ${ }^{1}$ University of Würzburg, \\ Chair for Human \\ Resource Management \\ and Organisation, Sanderring \\ 2, 97070 Würzburg, Germany \\ Full list of author information \\ is available at the end of the \\ article
}

\begin{abstract}
This paper shows that young men who completed an apprenticeship education plus a tertiary vocational education have considerably higher earnings during the first half of their career than those who obtained an academic education in addition to their apprenticeship education. We match employees with a tertiary vocational and an academic education based on their labour market experience and their individual and employer characteristics during their formative apprenticeship training years in which they presumably decided on their further education track. Then we compare the earnings developments in both groups of the matched sample during their tertiary education phase and after its completion for maximally 16 years after apprenticeship completion. We use linked employer-employee data of the IAB (LIAB9310).
\end{abstract}

Keywords: Tertiary education, Vocational education, Academic education, Earnings development, Propensity score matching

\section{Introduction}

There is a lively debate on differences between the returns of vocational in comparison to academic or general education (Eichhorst et al. 2015; Hanushek et al. 2017). It is however frequently overlooked in this debate that apprenticeship training does not equate to streaming into vocational education at the secondary level because a considerable share of former apprentices moves on to academic education in many countries (Ryan 2001). Besides academic education, many apprentices obtain vocational tertiary education. Vocational tertiary education however is comparable to academic education with respect to duration and is sorted into the same level in most professional classifications (OECD 2015).

This paper compares accumulated earnings of employees with a vocational tertiary education to academics when both groups have a completed vocational training on the upper secondary level. The comparison allows the assessment of the market value of vocational and academic education for relatively homogeneous groups of employees. Besides having a comparable education history, employees in both comparison groups have the ambition to add a higher education after having obtained an occupation that

(c) The Author(s) 2020. This article is licensed under a Creative Commons Attribution 4.0 International License, which permits use, sharing, adaptation, distribution and reproduction in any medium or format, as long as you give appropriate credit to the original author(s) and the source, provide a link to the Creative Commons licence, and indicate if changes were made. The images or other third party material in this article are included in the article's Creative Commons licence, unless indicated otherwise in a credit line to the material. If material is not included in the article's Creative Commons licence and your intended use is not permitted by statutory regulation or exceeds the permitted use, you will need to obtain permission directly from the copyright holder. To view a copy of this licence, visit http://creativeco mmons.org/licenses/by/4.0/. 
gives access to the skilled labour market (Rzepka 2018). Homogeneity of academics and employees with vocational tertiary education with respect to career orientation and schooling efforts allow us to effectively control for the endogeneity of educational path choice. The earnings differences we calculate therefore can be interpreted as causal effects of differences in the choice of the education path. So far, most comparisons of the returns to education of vocational and academic education are on secondary education or they do not take into account differences in the prestige and selectivity of vocational and academic education (Verhaest and Baert 2018).

Besides calculating the earnings differences in vocational vs. academic education, the question whether tertiary vocational education is an attractive alternative to academic education also is important in its own right, however. The group of those with completed apprenticeship training who are interested in a tertiary education and have the choice between vocational and academic education track is large and growing in Germany (Rzepka 2018).

Our contributions to the literature on the returns to academic versus vocational training are: first, we address the selection bias into academic vs. vocational tertiary education by identifying and using comparable homogeneous employee groups that are matched on individual labour market value during apprenticeship training. Second, we calculate the returns to tertiary vocational education in comparison to tertiary academic education in a lifetime earnings approach using detailed administrative earnings spell data for the first half of the employees' career. Third, we contribute to the discussion of the labour market acceptance of vocational careers in comparison to academic careers at the tertiary education level by comparing institutional differences between both education paths.

The paper is structured as follows. "Tertiary vocational education" describes the institutional background of tertiary vocational education in Germany. "Data, sample and description" presents our data and sample. "Empirical method" discusses our empirical method to calculate differences in lifetime earnings of employees with tertiary vocational and academic education. The results of the earnings comparisons are presented in "Results". In "Robustness Checks", several robustness checks are shown. "Discussion" discusses our results and concludes.

\section{Tertiary vocational education in Germany}

This paper calculates differences in earnings for people with tertiary vocational and academic education. In order to compare earnings of a homogeneous group of employees, we only include employees who in principle could have chosen both education tracks. More specifically, all employees in our sample completed an apprenticeship on the secondary level that is necessary to start with a tertiary vocational education and that is used by a substantial share of academics as a first degree before their tertiary education. The typical course of career events for people in our sample is depicted in Fig. 1. In order to understand our sample of employees better, we first characterize the German vocational training system with its secondary and tertiary education levels.

The dual apprenticeship training system is an important and successful component of the German education system. Apprenticeship training in Germany traditionally provides general and vocational education at the upper-secondary level for the majority of 


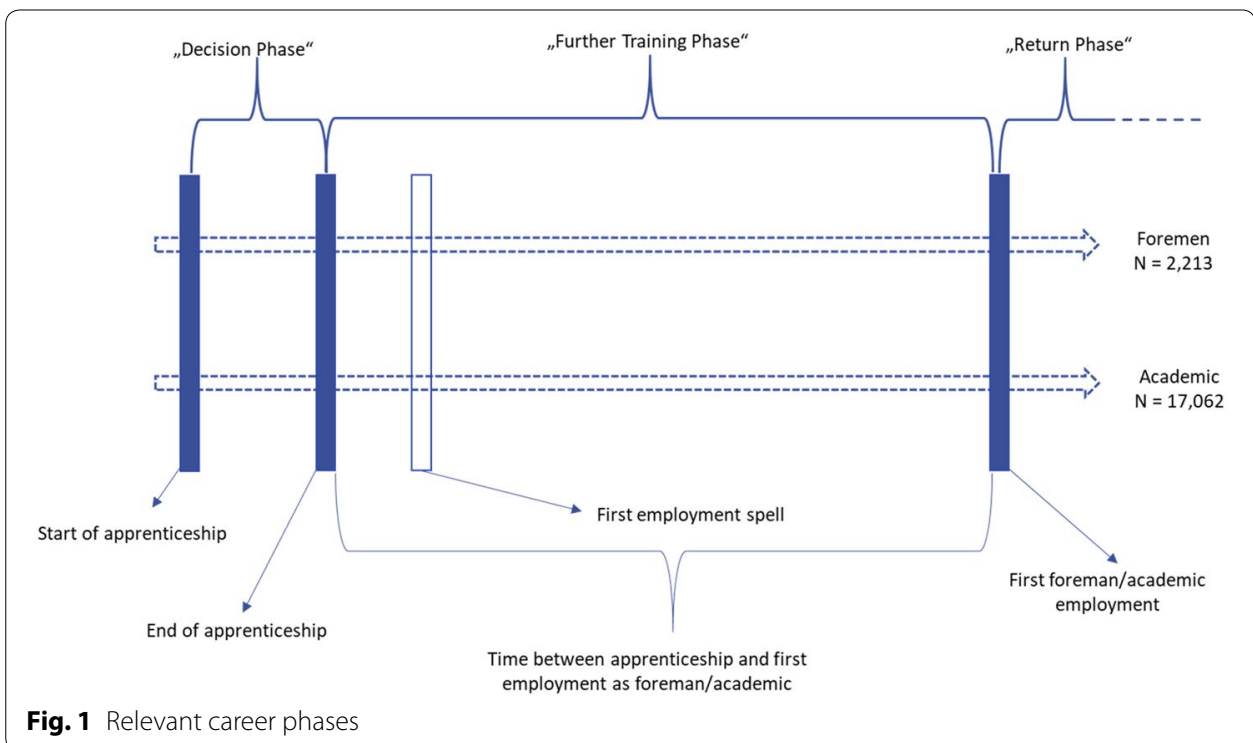

the German workforce and it therefore is the backbone of medium-skilled occupational training. Until the year 2012, the highest occupational level of more than $50 \%$ of the German population was a completed dual apprenticeship. In 2016, this share slightly fell to 47.2\% (Autorengruppe Bildungsberichterstattung 2018, Table B5-4web). We have to take into account that in addition to about half of the population with a completed apprenticeship "only", a substantial share of people with a tertiary education also completed an apprenticeship. This paper concentrates on the group of people with a completed tertiary education after their apprenticeship because providing career perspectives for employees who completed apprenticeship training is crucial to keep the apprenticeship system attractive and improves the pool of applicants for apprenticeship training.

The tertiary vocational education certificate (in Germany frequently called, "Meister" or "Techniker") is a widely recognised education that allows a career in the framework of the German vocational education system. Around $20 \%$ of apprenticeship completers obtain a tertiary vocational education certificate. ${ }^{1}$ In order to be allowed to attend tertiary vocational education, it is necessary to have completed an apprenticeship. The tertiary vocational education certificate guarantees general and transferable skills and it is granted by independent public bodies, the chambers of commerce and the chambers of craft. The certification therefore is analogous to apprenticeship training at the uppersecondary level, compare Acemoglu and Pischke (2000). The most important trait of the apprenticeship system is that the certificate is well known to most employers. In addition, the education contents are standardised and transparent, leaving the employer that contributed to education and their costs after completing foremen education is costless and possible directly after completion. Also analogously to apprenticeship training at

\footnotetext{
1 The shares can be constructed by dividing the number of people participating in further training provided by the chambers of commerce or chambers of craft by the number of people who completed an apprenticeship training, compare DIHK (2018). The exact figures are 23\% for 1995 and 21\% for 2017.
} 
the secondary schooling level, the costs for the foreman education are jointly borne by the state, employer and the employees. ${ }^{2}$ The state subsidises occupational schools and the certification bodies. In addition, analogously to means-tested subsidies for students, there are also subsidies for tertiary vocational education. ${ }^{3}$ About half of the foremen used public subsidies, mainly the Federal Training Assistance (Aufstiegs-BAföG) in the period 2012-2017 (DIHK 2018). The employers may provide practical training of those in tertiary vocational education at their own costs, about $30 \%$ of foremen received financial or other support from their employers (DIHK 2018). The employees either reduce their working hours (part-time education) or they stop altogether with their work (fulltime education). In addition, they have to pay considerable education fees.

As an alternative to a vocational career, many apprenticeship completers also have the option to obtain an academic certificate from a university or a university of applied sciences. More than one fifth of apprenticeship completers already has a university entrance certificate (Abitur) (Adda et al. 2013) and this group can study at an academic institution directly after completing apprenticeship training or after a work spell without additional requirements. In addition, there are mainly two pathways for non-traditional students who are vocationally trained but do not have sufficient schooling to get direct access to academic education: they either take Abendschule (evening school) during or after apprenticeship training or an entrance exam provided by the academic institution for applicants with completed vocational training but without Abitur (Wolter et al. 2014). ${ }^{4}$ Reasons mentioned for obtaining an apprenticeship certificate before an academic study are risk reduction (Büchel and Helberger 1995) and getting occupational practice for the academic job (Lewin et al. 1996). Some apprentices also may discover their career orientation during the apprenticeship training.

Tertiary vocational and some academic degrees are classified at the same level according to the International Standard Classification of Education, ISCED 2011 level 6. ${ }^{5}$ The German tertiary vocational education is therefore comparable for example to the polytechnics vocational bachelor degrees obtained in Finland, Norway, the Netherlands (Böckerman et al. 2018) or Switzerland (Tuor and Backes-Gellner 2010). In 2014, around 40.000 individuals completed tertiary vocational training in Germany (BIBB 2016).

Although so many apprenticeship completers in Germany obtain a tertiary vocational education in Germany and the organisation of this education degree is comparable to the well-known dual apprenticeship system at the secondary education level, relatively little is known about the returns to education from it. The obvious comparison group of the effect of a foremen degree on earnings seems to be an academic degree at the same professional certification level.

\footnotetext{
${ }^{2}$ A full-time foreman education costs about 5000€, BMBF (2019).

${ }^{3}$ See https://www.bundesregierung.de/Content/DE/Artikel/2015/10/2015-10-14-dritte-novelle-meister-bafoeg.htm.

4 Some academic institutions even offer academic education specifically for apprenticeship completers without university entrance exams, for example the so-called cooperative study with integrated apprenticeship training (Kooperatives Studium mit integrierter Ausbildung).

5 Before the introduction of the Bachelor and Master system, vocational tertiary education was classified at the same level as a diploma from Universities of Applied Sciences (Fachhochschulen). After the introduction of both academic levels during the Bologna process, they are classified at the same level as a Bachelor's degree at universities and a Master's degree at universities of applied sciences.
} 


\section{Previous literature on returns to vocational and academic training}

Brunello and Rocco (2017, p. 106) summarize the discussion on differences between the returns to vocational and academic training as follows: "Education economists often point out that individuals with a vocational education face a trade-off between short term benefits and long term costs. In the short term, this type of education facilitates the transition from school to the labour market by providing ready to use skills. In the long term, however, vocational skills depreciate relatively fast and individuals who specialize in these skills are less capable of adapting to technical change than individuals endowed with a more academically oriented education." The main argument for higher returns to vocational education at the start of the career is that vocational education provides ready to use skills, facilitates the transition from school to work, and therefore leads to a higher labour market value in comparison to general or academic training (Cörvers et al. 2011; Wolter and Ryan 2011; Fersterer et al. 2008). This advantage may however come at the price of vocational skills becoming quickly obsolete in modern economies characterised by rapid technological change (Bennett et al. 1995; Krueger and Kumar 2004; Golsteyn and Stenberg 2017; Hanushek et al. 2017; Brunello and Rocco 2017). Therefore, there may be a turning point during the career when lifetime earnings from academic education surpass earnings from tertiary vocational education (Bennett et al. 1995; Hanushek et al. 2017). It remains unclear however how strong the financial advantage of vocational tertiary education is and at which age occurs the break-even point.

Previous empirical contributions found mixed results on the returns to vocational in comparison to academic education. The first group of papers compares the returns to vocational vs. academic education including employees with several education levels. As the vocationally trained have a lower education level on average, the studies usually find higher earnings for those with an academic education in the long run and for lifetime earnings (compare Flake et al. 2016 and Rzepka 2018 for Germany, Hanushek et al. 2017 for a sample of 11 countries). For Switzerland, Tuor and Backes-Gellner (2010) however do not find differences in net earnings between those who obtained a foreman certificate or a university of applied science certificate and those who obtained a university certificate.

The second group of studies compares returns to education at the same education level and therefore it is closer to our approach. Most of these empirical papers therefore find that more general education contents in a given education track pay off only in the long run in comparison to more vocational contents (if at all), compare Dearden et al. (2002) for the UK, Bishop and Mane (2004) and Meer (2007) for the USA, Fersterer et al. (2008) for Austria, Cörvers et al. (2011) for Germany, the Netherlands, and the UK, Golsteyn and Stenberg (2017) for Sweden, Malamud and Pop-Eleches (2010) for Romania, Zilic (2018) for Croatia, and Brunello and Rocco (2017) for the UK.

Empirical research on the economic effects of education types mainly faces the task of controlling in a credible way the endogenous selection into different curricula and education tracks (Blundell et al. 2000, 2005; Brunello et al. 2017). In other words, unobservables may have an important impact on education choice as well as on earnings. Some papers use ordinary least squares wage equations (Blundell et al. 2000). They can be interpreted as regression based linear matching (Heckman et al. 1998). The control function estimators aim at putting enough structure to completely model the selection 
decision into the schooling track. Many obvious drivers of earnings potential and career intentions such as motivation or ability are hard to control with this approach, however. Some papers therefore compare earnings of same-sex full siblings (Golsteyn and Stenberg 2017) or use matching functions (Rzepka 2018) in order to get rid of heterogeneity. Other studies on returns to education use instrumental variables estimators and attempt to control for the correlation between otherwise unobserved individual factors and schooling choices by way of an excluded instrument, which is an education determinant which is independent of earnings (Card 1999), compare Hanushek et al. (2017). The third group of studies uses natural experiments that ideally split homogeneous groups of people in a treatment group with changes in education requirements or options and a control group without these changes. Examples of exogenous variations used to calculate differences in earnings by education path are changes in the compulsory shares of vocational and general content of education (Malamud and Pop-Eleches 2010; Hall 2016; Zilic 2018), the addition of one or two years of compulsory schooling (Pischke and von Wachter 2008; Bhuller et al. 2017), or the unexpected closure of firms that offered apprenticeship training (Fersterer et al. 2008; Hanushek et al. 2017).

In order to calculate the earnings differences between vocational and academic education, this paper for the first time combines two important steps that reduce potential estimation biases. First, we only compare vocational and academic education at the same-tertiary-level. Second, for matching it is important that during the period before the treatment decision, treatment and non-treatment pairs are observationally equal. We therefore only compare people who pursue (and complete) an apprenticeship training before choosing tertiary education. Unobservable yet decisive factors for earnings potential and career orientation therefore should be comparable (Dearden et al. 2002; Brunello and Rocco 2017). Most academics in Germany for example do not have apprenticeship training and therefore do not regard their academic studies as an alternative to a vocational career option. In addition, apprenticeship completers who obtain a tertiary vocational education may not be comparable to the average apprenticeship completer with respect to skills and abilities. We therefore argue that academics with a completed apprenticeship and apprenticeship completers with a tertiary vocational education are more homogeneous comparison groups than all employees with a completed vocational training on the secondary level and all academics. ${ }^{6}$

In addition to the sample reduction on people with completed apprenticeship training, we match employees with a tertiary vocational and employees with an academic education using propensity score matching. We argue in detail in the empirical methods section why using individual, occupation, and employer information from the apprenticeship training period captures the earnings potential of an employee better than using for example test results or other individual characteristics from school age as indicators for earnings capacity.

\footnotetext{
${ }^{6}$ Concentrating on tertiary vocational and academic education has the additional advantage in comparison to studies on the returns to education of employees with secondary education that the education obtained usually is the highest education. We cannot exclude that earnings later during the career are influenced by differences in learning on the job and continuing training participation. These differences in personnel development are regarded as part of the package included by the education track choice, however. Cörvers et al. (2011) argue that employees with general training may profit more from training than vocationally trained employees.
} 


\section{Data, sample and description}

We use the longitudinal Linked Employer-Employee Panel Data of the Institute of Employment Research (IAB) in Nuremberg for a maximum period of 1993-2010 (LIAB 9310). Our observation period of maximally 17 years means that we can construct earnings profiles during the entire first half of the career for many employees after completing their apprenticeship. Our panel data set allows us to separate cohort from age effects. We therefore can control for business cycle effects at the first labour market barrier (start of the apprenticeship), during the tertiary education phase, and after having obtained the vocational or academic tertiary education degree in addition to birth year and age.

Individual social security records are linked with the employer survey of the IAB Establishment Panel. The employer data for example include information about the establishment size, industrial relations, and sector. It seems important to control for employer characteristics because apprentices from small and low-paying training employers might have a different market value and different incentives to obtain a vocational or academic tertiary education than those having obtained their secondary vocational degree from a prestigious, large and well-paying employer (Dellas and Sakellaris 2003). In addition, selection into large industrial firms and well-paying apprenticeship occupations is important information on the selection at the first labour market barrier that indicates the labour market value of the apprentice (Soskice 1994).

The administrative employee data include information about schooling plus occupational education, daily earnings, occupation, employment spells, apprenticeship spells, and unemployment spells, as well as age, tenure, gender, and work experience (Alda et al. 2005; Jacobebbinghaus and Alda 2007). The administrative individual data have the advantage that they are essentially free of reporting errors because this information is used to calculate social assistance, earnings taxes, and old age pension entitlements. There might be some problems with the schooling information because this variable might not be updated or reported with errors by the employer (Fitzenberger et al. 2005). We take our crucial information on completing tertiary vocational or academic education however from another variable in the data, the so-called "occupational status at the employer" (Stellung im Beruf und Arbeitszeit). This variable supposedly is more accurate than the schooling information because it is directly related to the topical work position of the employee. The work position however is more relevant for earnings than education level. Employers have to actively change the information on the work position of employees who have been first classified as skilled employees with a dual apprenticeship after they completed their vocational or academic tertiary level degree and now work in an adequate position for employees with a completed tertiary education. The same reasoning applies for employer changers who have been classified as apprentices or as skilled employees with a completed apprenticeship in an earlier employment spell and later are classified as academics or foremen. ${ }^{7}$ We therefore can be sure that we observe only employees with an adequate position and drop employees from our sample who 
completed their vocational or academic tertiary level degree but still work as skilled employees at the upper-secondary level or founded their own business. ${ }^{8}$

Another well-known problem of our data set is that we do not observe the number of hours worked per day for people in part-time employment. This information deficit however does not play a big role in calculating lifetime earnings because we are interested in cumulated absolute earnings and not hourly earnings. We therefore also include part-time employment spells. Finally, employees with earnings above the social security threshold have only the threshold reported and therefore right-censored income. As we mainly look at earnings during the first career years, the share of censored income observations is small, however. ${ }^{9}$ We impute true earnings using a procedure proposed by Gartner (2005). We also check the robustness of our results when we only include observations without censoring.

In a first step, we identify all male apprentices who completed the dual apprenticeship training between 1993 and $2007(\mathrm{~N}=272,439)$. For this period, we have full information about the training and labour market biography. The restriction of the observation period to the year 2007 is necessary, in order to observe the apprentices with completed education for at least three years after they finished their apprenticeship. Studies have shown that males and females pursue different strategies in selecting educational tracks (Golsteyn and Stenberg 2017). Therefore, we only include males within our sample ${ }^{10}$ because most occupations with a large share of foremen are dominated by males, for example those in the metal industry. In addition, we only keep occupations and professions for which vocational and academic education at the tertiary level is possible (e.g. no hairdressers).

The identification of a successful completion of vocational and academic education at the upper-secondary and tertiary level with Social Security Records data requires certain assumptions. The data only entail information on the status as apprentice, which makes it difficult to distinguish between dropouts and successful apprenticeship completion. About two thirds of dropouts however occur within the first year of apprenticeship training (BIBB 2016). Therefore, we drop all apprenticeship spells with a training period shorter than 1.5 years to ensure that only successful apprenticeship completers are included within our sample.

In a second step, we restrict our sample to apprentices who either complete tertiary vocational or tertiary academic education $(\mathrm{N}=25,191$ which is around $9.25 \%$ of the original sample). Further restrictions include a minimum age at the start of the apprenticeship of 15 years and a minimum age for foremen of 18 years. Further, we only include individuals who obtain their tertiary education after the apprenticeship. Our final sample before we perform the matching procedure includes 19,275 apprentices who either become foremen $(\mathrm{N}=2213)$ or academics $(\mathrm{N}=17,062) .{ }^{11}$

\footnotetext{
${ }^{8}$ We cannot exclude mis-reporting by employers with respect to occupational status and therefore there might be some employees who are indicated to work in a foremen position without having obtained a formal foremen certificate.

9 Censored income observations are below $2 \%$ in our sample.

${ }^{10}$ Males have relatively stable aggregate labour-force participation patterns. Our sample therefore avoids biases in returns to education because there are cohort-specific changes in work selection by females, see Hanushek et al. (2017).

11 The relatively low share of foremen in our sample in comparison to the share of people with a foreman certificate relative to academics with an apprenticeship certificate in the total population can be explained by two specificities of our sample: more foremen than academics found their own business and entrepreneurs drop out of the sample because
} 
Our spell data allow us to identify with daily accuracy the beginning and ending of the apprenticeship, the first employment spell(s) as skilled employee at upper-secondary level after apprenticeship completion, and the first employment spell(s) as skilled vocationally or academically skilled employee at the tertiary level (see Fig. 1).

From the apprenticeship period (decision phase), we determine the exact age at the beginning and ending of the apprenticeship at upper-secondary level, the schooling background of the apprentice, the year of the apprenticeship completion, and the daily wage at the end of the apprenticeship. We use the number of apprentices, the retention rate after apprenticeship training, the average income level within the training establishment and sector, size, and location as indicators of the quality of the apprenticeship training and the attractiveness of the training employer (Soskice 1994).

Simple comparisons between our groups of vocationally and academically trained employees including $\mathrm{t}$ tests show that employees with vocational tertiary education are about one year younger than academics when they complete their apprenticeship training, they earn a little less at the end of the apprenticeship, they are more likely to be trained in smaller establishments, and the average income level within the training establishment is lower. ${ }^{12}$ All differences of means between foremen and academics within the decision phase on the tertiary education path are statistically significant. These differences point at a lower schooling and ability background of employees with tertiary vocational training in comparison to employees with tertiary academic training at the first labour market barrier (apprenticeship training at the secondary training level).

Our second measurement period is between the completion of the apprenticeship and the first employment as a completer of a vocational or academic tertiary education (education phase). Foremen gain more full-time working experience within this period than academics, they work less in part-time, they spend more days in unemployment and less time outside of the labour market, compare Table 1. Again, all differences of means are significant and intuitive given that a vocational education on the tertiary level is closer to the labour market than an academic education. Foremen can choose between a full or part-time further education model. The education phase is about one year longer for academics than for foremen although they work less during their education.

Our third measurement period starts with the first employment as academic or foreman (return phase). Foremen are about 1.2 years younger when they start to work as foremen and they are employed in smaller establishments than academics (compare Table 1). Furthermore, the average income level of the establishments where foremen start is lower. Again, the differences of means are statistically significant. In contrast, the differences of means of the entry wages as academic or foreman are statistically insignificant.

We want to compare those foremen and academics who had a comparable labour market value and labour market prospects at the start into their labour market career

Footnote 11 (continued)

it only covers employees. In addition, more foremen than academics do not work in an adequate occupational or professional position.

12 See Table 1 for detailed descriptive information before matching. 
Table 1 Descriptive statistics before matching

\begin{tabular}{|c|c|c|c|c|}
\hline \multirow[t]{2}{*}{ Variables } & \multirow{2}{*}{$\begin{array}{l}\text { Foremen } \\
\mathrm{N}=2213 \\
\text { Mean (SD) }\end{array}$} & \multirow{2}{*}{$\begin{array}{l}\text { Academics } \\
\mathrm{N}=17,062 \\
\text { Mean (SD) }\end{array}$} & \multirow[t]{2}{*}{ t test } & \multirow[t]{2}{*}{ Definition } \\
\hline & & & & \\
\hline \multicolumn{5}{|l|}{ "Decision phase" } \\
\hline $\begin{array}{l}\text { Age at the start of apprentice- } \\
\text { ship }\end{array}$ & $18.64(3.38)$ & $19.38(2.66)$ & 11.90 & In years \\
\hline $\begin{array}{l}\text { Age at the end of apprentice- } \\
\text { ship }\end{array}$ & $21.22(3.19)$ & $21.97(2.40)$ & 9.34 & In years \\
\hline Schooling background & $0.04(0.19)$ & $0.32(0.47)$ & 27.59 & $\begin{array}{l}\text { Dummy variable for A-level at the } \\
\text { end of apprenticeship training }\end{array}$ \\
\hline $\begin{array}{l}\text { Daily wage at the end of } \\
\text { apprenticeship }\end{array}$ & $3.18(0.48)$ & $3.26(0.47)$ & 7.13 & $\begin{array}{l}\text { Daily log wage at the end of } \\
\text { apprenticeship }\end{array}$ \\
\hline Number of apprentices & $103.42(340.40)$ & $115.51(368.15)$ & 1.47 & $\begin{array}{l}\text { Number of apprentices within } \\
\text { the training establishment } \\
\text { at the end of apprenticeship } \\
\text { training (foremen median = } 3 \\
\text { academics median= } 4 \text { ) }\end{array}$ \\
\hline \multicolumn{4}{|l|}{ Retention rate } & \multirow{2}{*}{$\begin{array}{l}3 \text { categories: how many } \\
\text { apprentices stay in the training } \\
\text { establishment after they finish } \\
\text { apprenticeship training }\end{array}$} \\
\hline $\begin{array}{l}\text { Less than } 40 \% \\
40-60 \% \\
\text { More than } 60 \%\end{array}$ & $\begin{array}{l}0.40 \\
0.03 \\
0.57\end{array}$ & $\begin{array}{l}0.46 \\
0.05 \\
0.49\end{array}$ & & \\
\hline $\begin{array}{l}\text { Average income level in train- } \\
\text { ing establishment }\end{array}$ & $\begin{array}{l}4.26 \\
(0.32)\end{array}$ & $\begin{array}{l}4.41 \\
(0.32)\end{array}$ & 20.56 & $\begin{array}{l}\text { Average daily log wage for all full- } \\
\text { time employees in the training } \\
\text { establishment }\end{array}$ \\
\hline $\begin{array}{l}\text { Sector of training establish- } \\
\text { ment }\end{array}$ & & & & $\begin{array}{l}24 \text { categories based on the } 3 \\
\text { digit classification of economic } \\
\text { activities of the training estab- } \\
\text { lishment }\end{array}$ \\
\hline \multicolumn{3}{|l|}{ Size of training establishment } & & \multirow{2}{*}{$\begin{array}{l}3 \text { categories of employee } \\
\text { numbers }\end{array}$} \\
\hline $\begin{array}{l}\text { Less than } 250 \text { employees } \\
\text { 250-1000 employees } \\
\text { More than } 1000 \text { employees }\end{array}$ & $\begin{array}{l}0.66 \\
0.18 \\
0.16\end{array}$ & $\begin{array}{l}0.49 \\
0.26 \\
0.25\end{array}$ & & \\
\hline $\begin{array}{l}\text { Location of training establish- } \\
\text { ment }\end{array}$ & 0.75 & 0.85 & & $\begin{array}{l}\text { Dummy variable for Western/ } \\
\text { Eastern Germany built from } \\
\text { dummy variables for federal } \\
\text { states }\end{array}$ \\
\hline Length of apprenticeship & $2.14(0.77)$ & $1.97(0.73)$ & 12.09 & $\begin{array}{l}\text { Time in years between appren- } \\
\text { ticeship start and apprentice- } \\
\text { ship end }\end{array}$ \\
\hline Occupation of apprenticeship & & & & $\begin{array}{l}2 \text { digit level occupations (99 } \\
\text { occupation dummies) }\end{array}$ \\
\hline \multicolumn{5}{|l|}{ "Education phase" } \\
\hline Full-time work experience & 0.71 & 0.29 & & $\begin{array}{l}\text { Share of time between appren- } \\
\text { ticeship and start as foreman or } \\
\text { academic }\end{array}$ \\
\hline Part-time work experience & 0.07 & 0.18 & & $\begin{array}{l}\text { Share of time between appren- } \\
\text { ticeship and start as foreman or } \\
\text { academic }\end{array}$ \\
\hline Unemployment period & 0.09 & 0.04 & & $\begin{array}{l}\text { Share of time between appren- } \\
\text { ticeship and start as foreman or } \\
\text { academic }\end{array}$ \\
\hline Time outside of labour market & 0.13 & 0.49 & & $\begin{array}{l}\text { Share of time between appren- } \\
\text { ticeship and start as foreman or } \\
\text { academic }\end{array}$ \\
\hline $\begin{array}{l}\text { Time between apprentice- } \\
\text { ship and start as foremen/ } \\
\text { academic }\end{array}$ & $2367.84(1355.71)$ & $2633.58(943.17)$ & 1.77 & $\begin{array}{l}\text { Time in days between appren- } \\
\text { ticeship and first employment } \\
\text { as academic or foreman }\end{array}$ \\
\hline \multicolumn{5}{|l|}{ "Return phase" } \\
\hline Occupation & & & & 2 and 3 digit level occupations \\
\hline
\end{tabular}


Table 1 (continued)

\begin{tabular}{|c|c|c|c|c|}
\hline Variables & $\begin{array}{l}\text { Foremen } \\
\mathrm{N}=2213 \\
\text { Mean (SD) }\end{array}$ & $\begin{array}{l}\text { Academics } \\
\mathrm{N}=17,062 \\
\text { Mean (SD) }\end{array}$ & $t$ test & Definition \\
\hline $\begin{array}{l}\text { Age at first employment as } \\
\text { academic or foremen }\end{array}$ & $27.91(4.49)$ & $29.12(3.21)$ & 15.78 & In years \\
\hline $\begin{array}{l}\text { Location of entry establish- } \\
\text { ment }\end{array}$ & 0.79 & 0.87 & & $\begin{array}{l}\text { Dummy variable for western/ } \\
\text { eastern Germany built from } \\
\text { dummy variables for federal } \\
\text { states }\end{array}$ \\
\hline Tenure & $2.60(3.81)$ & $0.78(1.42)$ & 43.45 & $\begin{array}{l}\text { In years if Academic/foreman } \\
\text { has been working in the entry } \\
\text { establishment before the start } \\
\text { as academic/foreman }\end{array}$ \\
\hline $\begin{array}{l}\text { Average income level of entry } \\
\text { establishment }\end{array}$ & $4.31(0.36)$ & $4.63(0.37)$ & 38.21 & $\begin{array}{l}\text { Log average daily wage for all } \\
\text { full-time employees in the } \\
\text { entry establishment }\end{array}$ \\
\hline $\begin{array}{l}\text { Same establishment as during } \\
\text { apprenticeship }\end{array}$ & 0.17 & 0.03 & & $\begin{array}{l}\text { Dummy variable: } 1 \text { if the first } \\
\text { employment as academic/fore- } \\
\text { man is in the same establish- } \\
\text { ment as the apprenticeship, } 0 \\
\text { otherwise }\end{array}$ \\
\hline $\begin{array}{l}\text { Same establishment as first } \\
\text { employment after appren- } \\
\text { ticeship }\end{array}$ & 0.20 & 0.05 & & $\begin{array}{l}\text { Dummy variable: } 1 \text { if the first } \\
\text { employment as academic/fore- } \\
\text { man is in the same establish- } \\
\text { ment as the first employment } \\
\text { after the apprenticeship, } 0 \\
\text { otherwise }\end{array}$ \\
\hline Size of entry establishment & & & & 3 categories of employee \\
\hline $\begin{array}{l}\text { Less than } 250 \text { employees } \\
250-1000 \text { employees } \\
\text { More than } 1000 \text { employees }\end{array}$ & $\begin{array}{l}0.75 \\
0.13 \\
0.12\end{array}$ & $\begin{array}{l}0.47 \\
0.25 \\
0.28\end{array}$ & & numbers \\
\hline Entry wage & $4.35(0.47)$ & $4.31(0.72)$ & 1.03 & $\begin{array}{l}\text { Log daily wage at employment } \\
\text { start as foreman/academic }\end{array}$ \\
\hline Economic sector & & & & $\begin{array}{l}24 \text { categories based on the } 3 \\
\text { digit classification of economic } \\
\text { activities of the training estab- } \\
\text { lishment }\end{array}$ \\
\hline
\end{tabular}

Source: LIAB longitudinal model 93-10

after apprenticeship training. Therefore, we propose a matching method to find suitable homogeneous couples based on individual and employer characteristics during apprenticeship training.

\section{Empirical method}

To recover the average treatment effect on the treated, we choose a propensity score matching method (Rosenbaum and Rubin 1983; Heckman et al. 1998; Smith and Todd 2005; Biewen et al. 2014; Hanushek et al. 2017). The matching method tries to mimic expost a natural experiment by choosing a comparison group from among the non-treated such that the selected group is as similar as possible to the treatment group in terms of their observable characteristics (Dehejia and Wahba 1999, 2002; Mueser et al. 2007). Our matching variables therefore aim to explain whether an apprentice chooses a vocational or academic tertiary education after completion and earnings during apprenticeship training. After adequately controlling for differences during the decision phase on tertiary education, we can interpret earnings differences after apprenticeship completion 
as treatment effect of a vocational versus an academic tertiary schooling choice (Heckman et al. 1998; Lechner 2002).

Although the sample reduction to employees with a tertiary vocational education and academics with a completed apprenticeship strongly reduces unobservable and observable differences in characteristics of employees with a vocational and with an academic education, both groups still show large differences in indicators of earnings potential and career intentions. We therefore use the 1:1 nearest neighbour matching to make foremen comparable to academics with respect to their tertiary education decision and their earnings potential (Stuart 2010; Rubin 1973; Smith and Todd 2005). The basic idea is to identify an academic who is as similar as possible to a foreman concerning all relevant pre-treatment characteristics. during the apprenticeship training period. As our control group is large enough, we perform matching without replacement to ensure, that every academic is matched only once. ${ }^{13}$ After the matching procedure, we have 2079 foremen and the same number of matched academics. ${ }^{14}$

We first assume that the quality of the apprenticeship training employer is an important indicator of earnings potential and career orientation because it indicates selectivity at the first labour market barrier for employees included in our sample (Von Wachter and Bender 2006). In Germany, is a clear hierarchy with respect to the attractiveness of apprenticeships and firms thoroughly screen their apprenticeship candidates (Soskice 1994; Winkelmann 1996). As a consequence, young people with a higher earnings potential and career orientation select themselves into larger and better paying training firms as well as into more attractive occupations and sectors (Soskice 1994). We therefore include the apprentice retention rate, size and sector of the training establishment, the number of apprentices, and the average income level in the training establishment are important matching variables.

Second, individual characteristics also reveal earnings potential and career orientation. Our individual indicators during apprenticeship training are occupation, age at the start of apprenticeship training (older apprentices frequently have a better professional orientation), prior education level, and length of apprenticeship period (more demanding apprenticeship programmes take longer). In addition, we use the labour market value of apprentices as revealed by their relative wage position within an occupation (compare Bhuller et al. 2017).

Finally, also the business cycle and temporary and regional labour market effects may influence the earnings potential and career decisions. Apprentices in depression phases may have higher incentives for obtaining tertiary education than apprentices with better options on the labour market directly after apprenticeship completion (Dellas and Sakellaris 2003). We therefore control for year and location in Western Germany. ${ }^{15}$

Most papers on the returns to education rely on (mainly) cognitive tests or standardised ability test as indicators of earnings potential. Examples of tests are the International Adult Literacy Survey (IALS), the American Forces Qualification Test (AFQT) the

\footnotetext{
${ }^{13}$ Matching with replacement can be helpful in settings with smaller control groups, see Dehejia and Wahba (1999).

14 Nearest neighbour matching with replacement and different specifications of kernel matching have been performed. As the results remain robust, we chose the most straight forward 1:1 nearest neighbour matching without replacement.

15 It has been shown, that the selection of relevant covariates is more important than the selection of the propensity score matching method (Cook et al. 2008; Pohl et al. 2009; Shadish et al. 2008).
} 
Programme for the International Assessment of Adult Competences (PIACC), Intelligence Quotient (IQ) tests results, or the OECD Programme for International Student Assessment (PISA) (Hanushek et al. 2017; Bhuller et al. 2017; Stenberg and Westerlund 2015; Heckman et al. 2018). Other frequently used matching variables for earnings potential and career orientation are school grades (Rzepka 2018), family background variables including parents' opinion on education, siblings or twins (Blundell et al. 2000, 2005; Golsteyn and Stenberg 2017), the number of books in the household or the economic situation during the schooling period (Card 1999; Brunello et al. 2017). Basic cognitive ability measured years before labour market entry (such as in AFQT or PISA or the family situation during youth) or during adulthood (such as in IALS) may influence earnings potential and career orientation differently for different education tracks, however. It may be argued, for example, that cognitive skills play a larger role for jobs mainly performed by people with an academic education and non-cognitive skills may be more important for jobs performed by employees with a vocational education (Heckman et al. 2006; Kahn 2013). Another problem of using cognitive test results in order to control for differences in earnings potential and career orientation is that labour market value also is determined by non-cognitive skills (Heckman et al. 2006; Schönberg 2007; Kahn 2013; Mohrenweiser et al. 2020). ${ }^{16}$ The importance of non-cognitive skills for earnings potential means that an important and independent dimension of ability is missing in most test indicators. Heckman et al. (2006) even argue that schooling and ability test scores obtained during and after schooling are correlated and might induce reverse causality (and therefore biases) in earnings estimations. As a consequence, according to our estimation strategy, also in the public training programme evaluation literature and in the returns to postsecondary education literature mainly earnings, individual labour market experience and labour market characteristics just before treatment are used as matching parameters (Heckman et al. 1998, 1999; Mueser et al. 2007; Böckerman et al. 2018).

Blundell et al. (2000) and Blundell et al. (2005) compare returns to education with and without earnings potential indicators. ${ }^{17}$ They find that the inclusion of family background, demographic and ability test information hardly changes the measured returns to education. The inclusion of topical job information (employer size dummies, union status and a public /private sector dummy) however has a strong impact on education returns. Past wage information therefore may be a better indicator of earnings potential and career orientation than ability indicators obtained before entry into the labour market (Kahn 2013). We therefore suggest to use previous earnings and labour market indicators instead of ability indicators from the time before the education is obtained as indicators for earnings potential and career orientation (Ryan 2001; Stenberg and Westerlund 2015; Biewen et al. 2014).

By conditioning on information during apprenticeship training such as market value or employer characteristics for our matching, we also control for state dependence that

\footnotetext{
${ }^{16}$ Heckman et al. (2006) for example show on the basis of the National Longitudinal Survey of Youth, 1979 (NLSY79) that non-cognitive skills measured by the Rotter Locus of Control Scale and the Rosenberg Self-Esteem Scale have a comparable impact on for example earnings as cognitive ability measured by the Armed Forces Qualifications Test (AFQT).

17 They use detailed test scores at age 7 and 11, mother's and father's education, age, father's social class when the child was 16 , mother's employment status when the child was 16 and the number of siblings the child had at 16 and school variables to control for ability.
} 
might be crucial for controlling for endogeneity. Early experience in the youth labour market has consequences for later decisions and labour market prospects (Ryan2001). For example, apprentices in high quality apprenticeship training programmes may have a higher propensity to opt for tertiary academic education than apprentices in small firms.

Although we do our best to control for selection into the educational track, we cannot be sure whether unobserved attributes nevertheless drive the earnings potential and career orientation. As a negative selection by ability into the vocational track will be shown later, the ceteris paribus prediction would be lower earnings for participants if vocational studies had no effect. The earnings advantage of the vocational track is therefore likely to be genuine and may be even larger if selectivity bias could be further reduced (Ryan 2001).

We use the sum of earnings added from spell data instead of current earnings patterns constructed from yearly average earnings or earnings at a selected day per year. Earnings sums are the preferred measure of returns to education because they avoid life cycle bias incurred by cross-section estimations, compare Bhuller et al. (2017) or Brunello et al. (2017). We use longitudinal spell data covering most of the age spectrum, which allows us to disentangle cohort, age and time effects. We take into account that future income has to be discounted. We therefore adjust earnings for inflation and use a discount rate of 2.4\% (Bhuller et al. 2017).

\section{Results}

Quality tests show that the matching procedure is able to balance the distribution of the relevant matching variables in both the control and treatment group. We assessed the standardised bias as suggested by Rosenbaum and Rubin (1985). The standardised bias for each covariate is defined as the difference of sample means in the treated and matched control subsamples as a percentage of the square root of the average of sample variances in both groups. One problem of this approach is that there is no clear benchmark indicating the success of the bias reduction. However, if the standardised bias is reduced below 5\% after matching, the method is considered effective (Caliendo and Kopeinig 2008). Figure 2 presents a graphical comparison of group differences before and after matching.The standardised bias for each covariate is lower than $5 \%$ after the matching procedure.

We also control for the matching quality using a two-sample $t$ test to check whether there are significant differences in covariate means for both groups (Rosenbaum and Rubin 1985). The tests show no significant differences after matching (see Table 2 for details).

The main finding is that the matched employees' earnings during their apprenticeship training are equal and we therefore assume that apprentices in both groups have comparable earnings ability.

Figure 3 shows the differences in log daily earnings of vocationally educated compared to their matched academics up to 16.5 years after their dual apprenticeship training (198 months). After our successful matching, there are no significant earnings differences during the apprenticeship period (see months -24 to 0 ). After the end of the apprenticeship, vocationally educated employees earn significantly more than academics. For example, five years (60 months) after the apprenticeship training, vocationally 


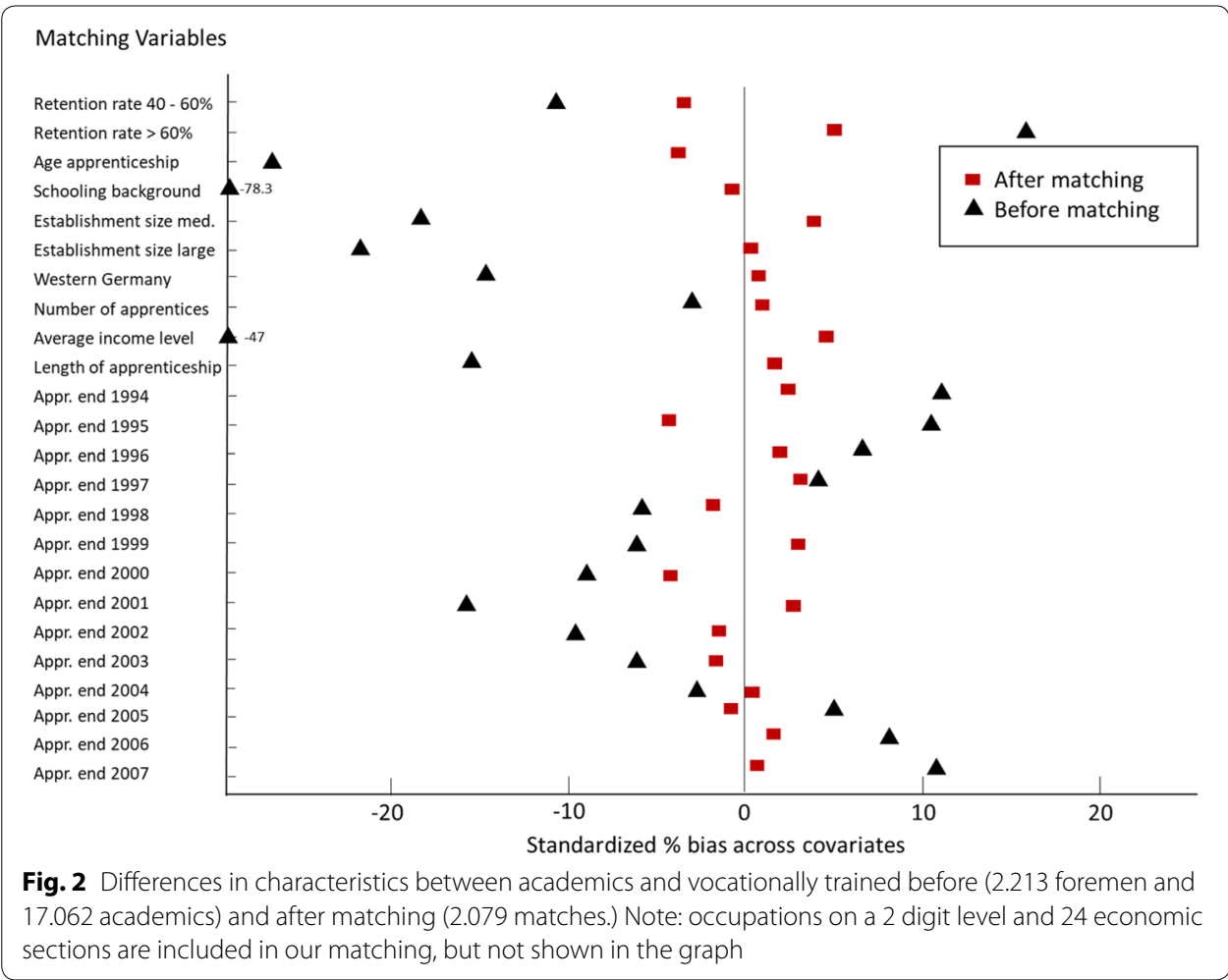

Table 2 Descriptive statistics after matching

\begin{tabular}{llll}
\hline Matching variables & $\begin{array}{l}\text { Foremen } \\
\mathbf{N = 2 0 9 7} \\
\text { Mean (SD) }\end{array}$ & $\begin{array}{l}\text { Academics } \\
\mathbf{N = 2 0 9 7} \\
\text { Mean (SD) }\end{array}$ & t test \\
\hline Age at the start of apprenticeship & $18.59(3.32)$ & $18.50(2.61)$ & 0.94 \\
Age at the end of apprenticeship & $21.37(3.14)$ & $21.22(2.34)$ & 1.61 \\
Schooling background & $0.04(0.20)$ & $0.05(0.22)$ & 1.22 \\
Daily wage at the end of apprenticeship & $3.18(0.48)$ & $3.09(0.51)$ & 0.91 \\
Number of apprentices & $106.30(343.75)$ & $108.68(386.46)$ & 0.20 \\
Retention rate & & & \\
Less than 40\% & 0.39 & 0.41 & \\
40-60\% & 0.03 & 0.04 & \\
More than 60\% & 0.58 & 4.55 & \\
Average income level in training establishment & $4.26(0.32)$ & & \\
Size of training establishment & & 0.63 & \\
Less than 250 employees & 0.66 & 0.19 & \\
250-1000 employees & 0.18 & 0.18 & \\
More than 1000 employees & 0.16 & 2.13 (0.76) \\
Location of training establishment & 0.72 & $2.14(0.77)$ & \\
Length of apprenticeship & &
\end{tabular}

Source: LIAB longitudinal model 93-10

educated employees earn on average 165\% more. Even 10 years after their apprenticeship training, the difference between log wages is still $45 \%$. This big advantage in earnings for vocationally educated is mainly a consequence of the fact that academics have a 


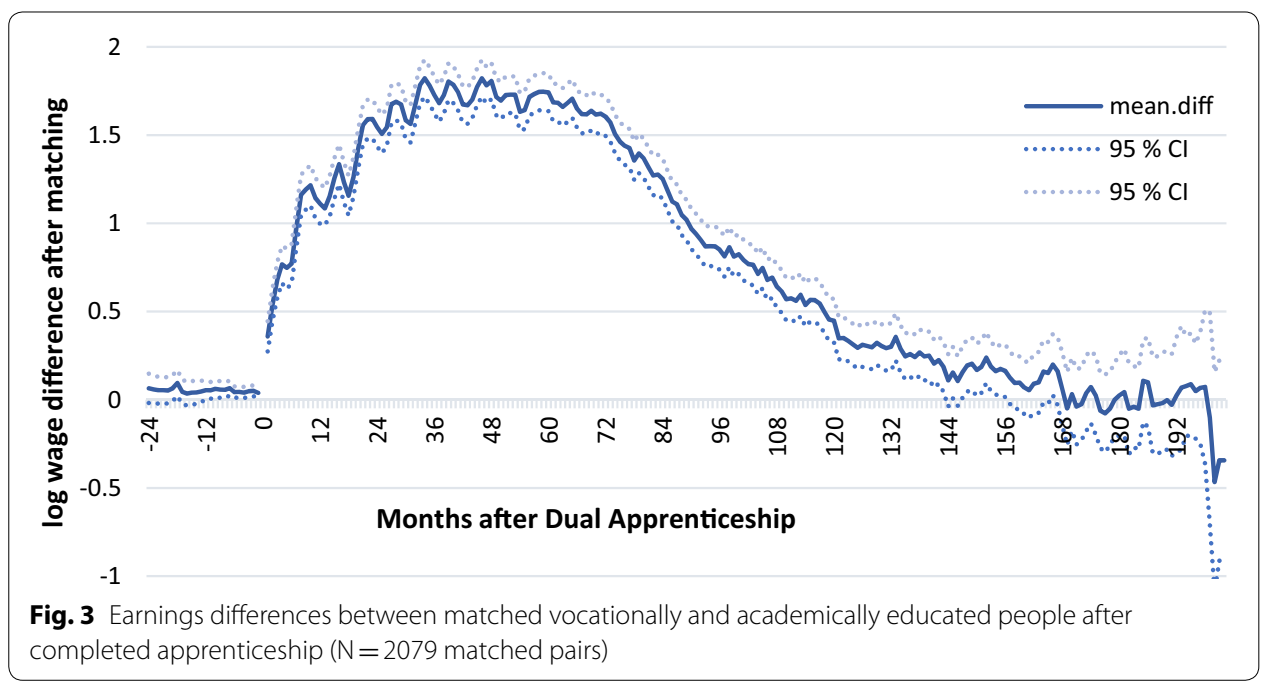

somewhat longer education phase and therefore start their professional working phase later in life. In addition, during vocational tertiary education chances to be employed are higher than during academic education.

A comparison of cumulative earnings differences in both groups shows that individuals with vocational tertiary education hold a substantial advantage in earnings (the maximum is at $122.000 €$, see Fig. 4). This advantage is higher than several average yearly earnings for both groups and it is only gradually reduced in later career years. ${ }^{18}$ As a consequence of the fact that entry earnings of those who just completed vocational tertiary education are higher than their academic matching partner, on average the turning point from which the earnings advantage starts to get reduced is only reached about thirteen years after the completion of apprenticeship training of the matched individuals (see Fig. 4). Even at the end of the observation period of more than 16 years after apprenticeship training, foremen have a substantially higher life time earnings level. More specifically, 16 years after apprenticeship training, foremen on average have an advantage in cumulative earnings of $107.000 €$ compared to the academically educated employees matched to them.

If we assume that the decline in the financial advantage of master craftsmen between the years 13 and 16 continues at the same pace, the financial advantage would have disappeared more than 20 years later or about 35 years after the end of the apprenticeship training. The foremen and academically educated employees in our dataset would be 57 years old by then.

\footnotetext{
${ }^{18}$ The earnings advantage amounts to about 4 2/3 yearly entry earnings for academics (27.444€, compare Appendix Table 1).
} 


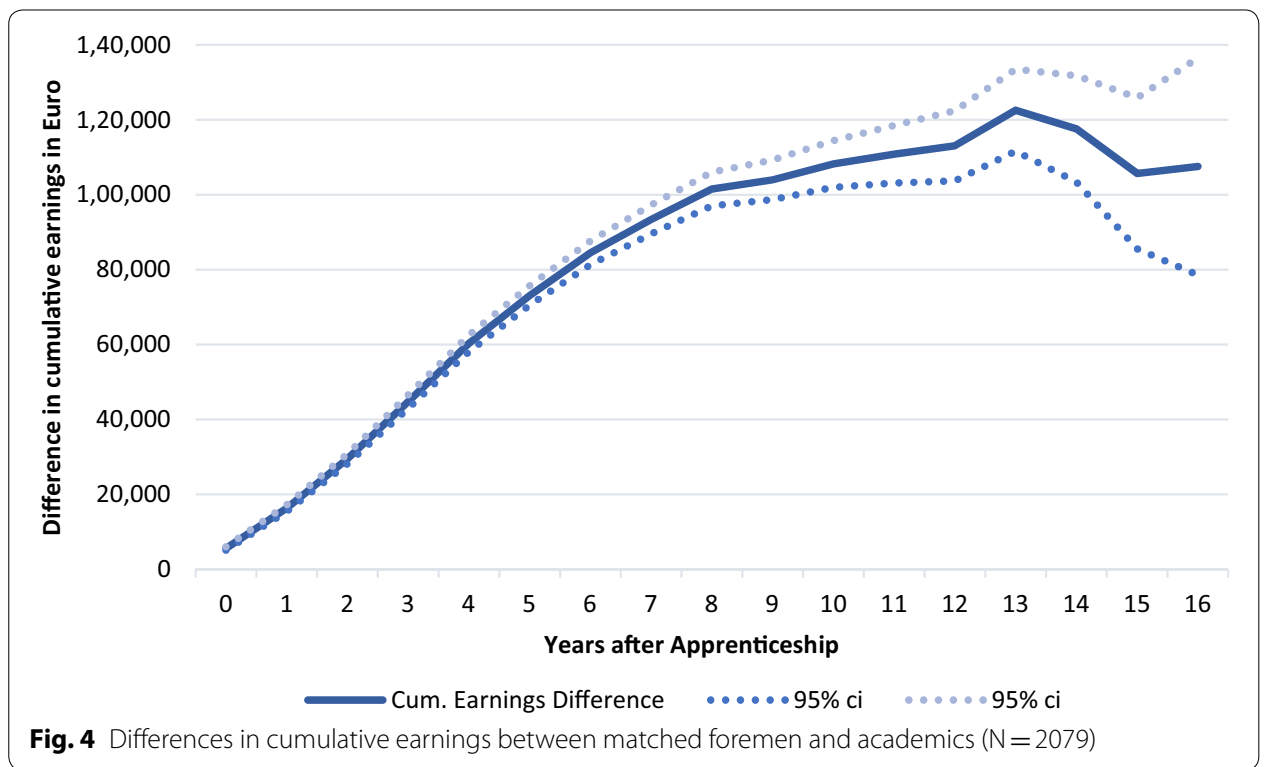

\section{Robustness checks}

We first compare our main results with a calculation of cumulative earnings without any matching procedure but still using a sample of academics with a completed apprenticeship training as comparison group. ${ }^{19}$ As shown in Appendix Figs. 5 and 6, the earnings advantage of foremen is a lot smaller (max. 61,300€) and declines already eight years after the apprenticeship training. 16 years after the apprenticeship, the financial advantage of foremen declined to not even $8500 €$. The big differences between matched and unmatched samples may be a result of the fact, that without an adequate matching procedure, foremen are compared with academics in actually not comparable occupations, at different times in their working career, and without comparable earnings potential already during the apprenticeship.

To make sure that our results are not driven by specific individuals in our matching sample, we also calculate earnings differences of matched sub-samples such as university (732 matches) and polytechnic (1365 matches) academics. The matching in these subsamples works effectively and we have similar earnings of foremen and their matched academics during the apprenticeship training. The log wage differences pattern looks similar to our results of the whole sample. The comparison of cumulative earnings between university academics and foremen shows that the higher earnings especially at the beginning of their career leads to a substantial advantage of $123.000 €$ after 10 years and about $166.000 €$ after 16 years (see Appendix Fig. 7). Compared to polytechnic academics, the earnings advantage of foremen is still substantial but lower. After 10 years foremen earn $99.000 €$ more and after 16 years the earnings advantage is still $83.000 €$ (see Appendix Fig. 8). The sub-sample comparison suggests, that university academics

${ }^{19}$ The alternative calculation is based on the sample described in Table 1. 
might reach higher earnings than foremen, but later (after our observation phase) in their working careers.

Additional sub-samples such as vocationally educated employees with highest education at the tertiary level with and without higher secondary schooling background ( $A b i-$ tur), apprentices in certain occupations or industries confirm our results (due to sample size restrictions, no detailed results are shown).

As we compare future earnings, discount rates have to be taken into account. Academics have higher earnings later in their career and therefore the discount rate might have an effect on the earnings comparison. We used different discount rates (see the results for zero and 5\% discount in Appendix Figs. 9 and 10). The results are only slightly affected by discount rates and we therefore chose a discount rate of $2.4 \%$ that has also been used in the previous literature (Bhuller et al. 2017).

In addition to the nearest neighbour matching method described above, we also compare earnings differences between vocationally and academically educated employees who completed their apprenticeship within the same year, in the same training establishment, and in the same occupation (on a two digit level). In our matching model, we do not use exact matching on these variables and therefore matched employees may come from different employers (we only match on employer size, location and sector, but it doesn't necessarily have to be the exact same employer) and have different occupations, for example. If we assume that the "formative years" during apprenticeship are decisive for the earnings potential, an exact matching on occupation and employer gives us a more adequate earnings comparison. The robustness check of course has the disadvantage that the number of comparable observations is strongly reduced and mainly comes from large training firms. In our twin sample we have 181 foremen and 350 academics because we only can include establishments with at least two apprentices who end their apprenticeship within the establishment in the same year and in the same occupation. The "new comparison confirms our previous findings and leads to an even higher financial advantage of foremen until the end of our observation period. More specifically, five years after the apprenticeship training, future foremen already earn $182 \%$ more than their academic counterpart. Thus, the earnings advantage is $17 \%$ bigger than in our previous findings (see Appendix Fig. 11). The comparison of cumulative earnings of our new comparison groups shows, that 10 years after the apprenticeship, foremen hold a financial advantage of $117,500 €$ (almost $10,000 €$ more than before). Thus, 16 years after the end of the apprenticeship training, the earnings advantage of foremen is about the same as in our matching sample (106,300€ instead of 107,000€). Appendix Fig. 11 reveals that we however get wide confidence intervals in our new comparison because the sample size is small.

\section{Discussion}

Policy choices lead to institutional differences in the provision of academic and vocational education and to differences in shares of people who choose one of the tracks and the labour market outcomes of these choices (Hanushek et al. 2017). 
We match individuals who are as similar as possible during their formative first labour market years, i.e. during their apprenticeship training. We therefore compare earnings of foremen with selected academics who have the same earnings capacity and career intentions during the period in which they decide whether to choose a tertiary vocational or academic education. The rich information about daily earnings plus the high quality matching results during the apprenticeship period allow us to interpret differences in the earnings developments during the tertiary education phase and after the first employment as foreman or academic as causal earnings effects of a tertiary level vocational vs. an academic education for employees in our sample.

This paper shows that employees with a tertiary vocational education earn more during the first years of their career than comparable academics. This is a strong result because it demonstrates that a vocational tertiary education is an attractive alternative to a more general academic education for comparable groups of employees. Our calculation includes the earnings advantages of tertiary vocational education obtained from better earnings opportunities during education and the shorter education period in comparison to an academic education. Our approach therefore deviates from many studies on returns to education that compare earnings levels after the completion of an education track, for example on the basis of the classical Mincer earnings equation. We however think that a life time earnings approach better depicts the relevant individual decision situation of young people who have both options, vocational and academic tertiary education. The vocational career options at the tertiary level also may increase the attractiveness of vocational training at the upper-secondary level given the path dependence in educational choices and advantages (Böckerman et al. 2018). Education options at the tertiary level with a strong vocational content could therefore help to avoid that vocational training at the upper secondary level is seen as a dead-end for low achievers such as is frequently the case for example in France, the USA or the UK (Ryan 2001). An apprenticeship instead may be attractive for young people who are uncertain whether a vocational or academic track is the right choice for them because they can use it as a career phase in which they can learn about their skills and preferences without giving up the option to get into an academic track (Ryan 2001). Tertiary vocational education also could be an efficient alternative for academic training in countries without a developed vocational education system at the level. Vocational tertiary education is relatively cheap in comparison to academic tertiary education (see the Tables B1 in OECD 2008) and it nevertheless produces comparable individual returns on the labour market and a comparable productive value on the labour market in the first half of the career. Especially in countries with a weak labour market performance of tertiary educated academics and/or strongly increasing tuition costs and the accumulation of large student debts, tertiary vocational education may be a good education option (Reyes et al. 2016).

This paper concentrates on the internal validity of measuring accumulated earnings for people with tertiary vocational training in comparison to academic training. We cannot generalize our findings to the bigger question of the returns of vocational vs. academic training in Germany or the (hypothetical) earnings effect of introducing tertiary vocational training in countries that do not have this option so far. In order to reduce 
biases of earnings differences to a minimum (rigor), we decided to select a sample of academics with completed apprenticeship training and therefore trade off some external validity of our findings (relevance).

\section{Conclusion}

We find that foremen earn significantly more during the first years after completing apprenticeship training than academics. Their financial advantage flattens off relatively fast, however. We show that foremen have on average achieved a cumulative earnings advantage of 122,000€. Even 16 years after the apprenticeship, foremen still have an earnings advantage of $107,000 €$. We also show that foremen start in an adequate job when they are about one year younger than academics. The age difference until an adequate job after tertiary education is found additionally increases the gap in cumulative earnings academics have to close during their working lifetime.

It remains a topic for future research whether also the lifetime income of foremen is higher in comparison to their comparison group of academics because our data cover only the first 16 years after completing apprenticeship training. If we assume that the reduction in the financial advantage of foremen decreases at the same pace as during the first years after the peak advantage for foremen, we obtain a reduction of the financial advantage to zero at about 57 years of age. Academics with a completed apprenticeship training therefore on average have a higher lifetime income than foremen.

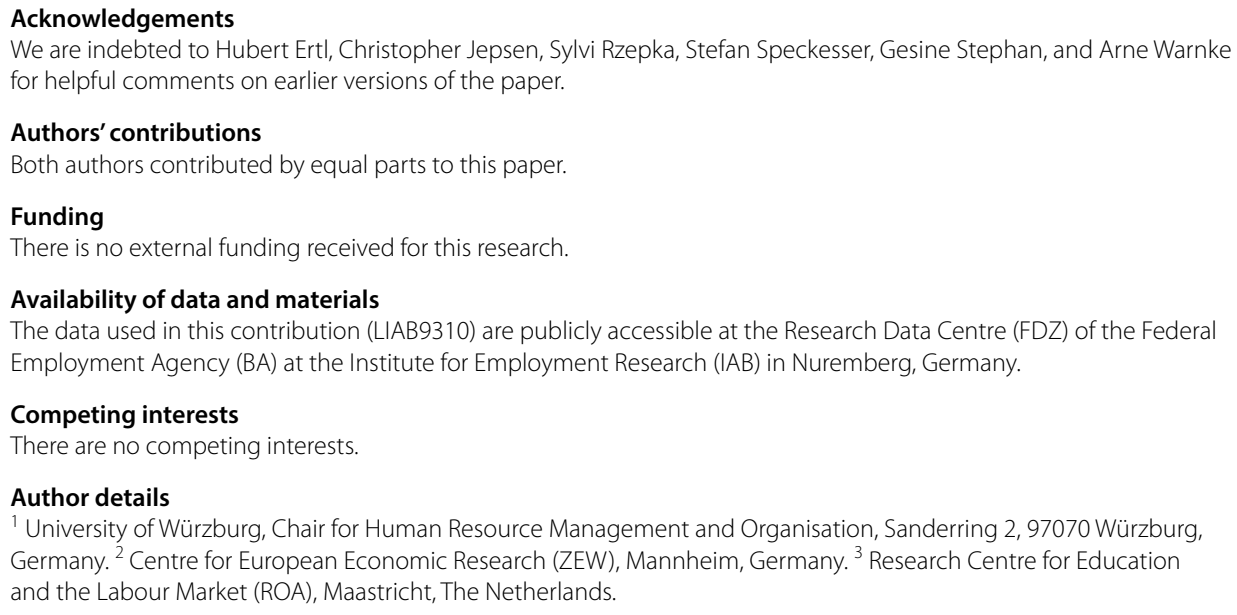

\section{Appendix}

See Table 3 and Figs. 5, 6, 7, 8, 9, 10, 11 . 
Table 3 Descriptive statistics after matching

\begin{tabular}{|c|c|c|c|}
\hline & $\begin{array}{l}\text { Foremen } \\
N=2097\end{array}$ & $\begin{array}{l}\text { Academics } \\
\mathrm{N}=2097\end{array}$ & $t$ test \\
\hline & Mean (SD) & Mean (SD) & \\
\hline \multicolumn{4}{|l|}{ "Education phase" } \\
\hline Full-time work experience & 0.72 & 0.31 & \\
\hline Part-time work experience & 0.05 & 0.14 & \\
\hline Unemployment period & 0.09 & 0.06 & \\
\hline Time outside of labour market & 0.14 & 0.49 & \\
\hline Time between apprenticeship and start as foremen/academic & $2400.79(1342.50)$ & $2837.77(1048.99)$ & 10.84 \\
\hline \multicolumn{4}{|l|}{ "Return phase" } \\
\hline Age at first employment as academic or foremen & $27.95(4.47)$ & $28.90(3.35)$ & 7.20 \\
\hline Location of entry establishment & 0.78 & 0.80 & 1.15 \\
\hline Tenure & $2.67(3.86)$ & $0.83(1.80)$ & 17.82 \\
\hline Average income level of entry establishment & $4.31(0.36)$ & $4.54(0.39)$ & 18.35 \\
\hline Same establishment as during apprenticeship & 0.17 & 0.04 & \\
\hline Same establishment as first employment after apprenticeship & 0.20 & 0.05 & \\
\hline \multicolumn{4}{|l|}{ Size of entry establishment } \\
\hline Less than 250 employees & 0.75 & 0.52 & \\
\hline 250-1000 employees & 0.13 & 0.25 & \\
\hline More than 1000 employees & 0.12 & 0.23 & \\
\hline Entry wage & $4.35(0.47)$ & $4.21(0.76)$ & 7.13 \\
\hline
\end{tabular}

Source: LIAB longitudinal model 93-10

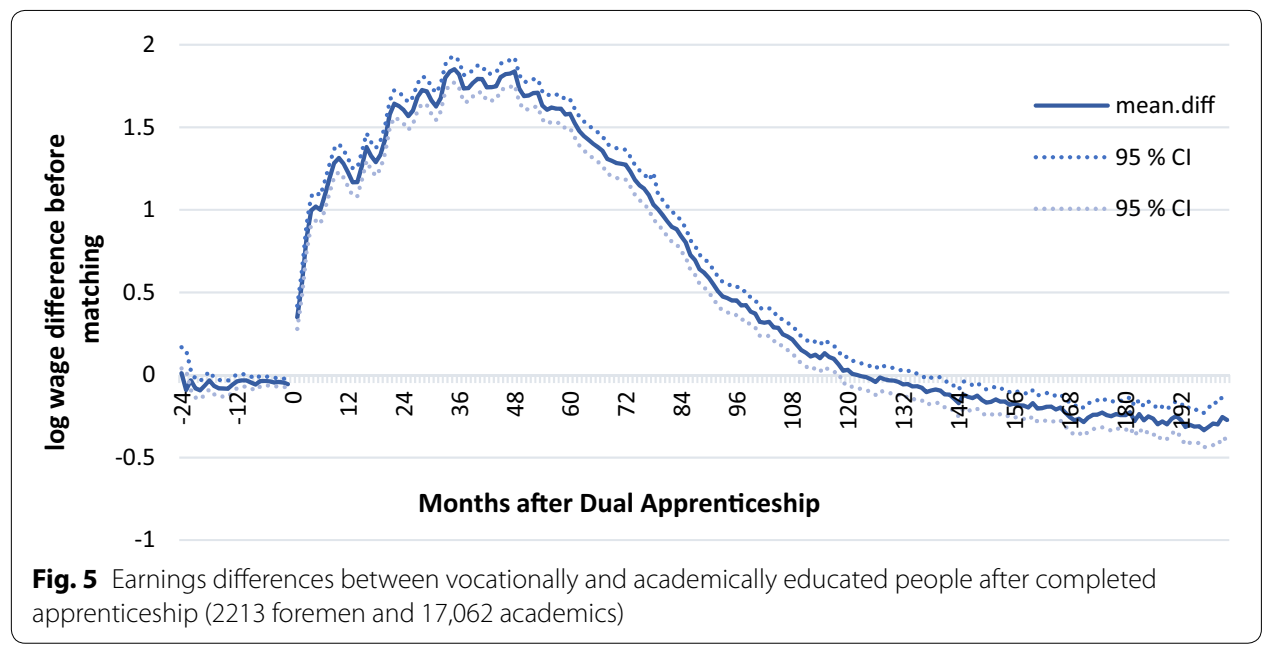




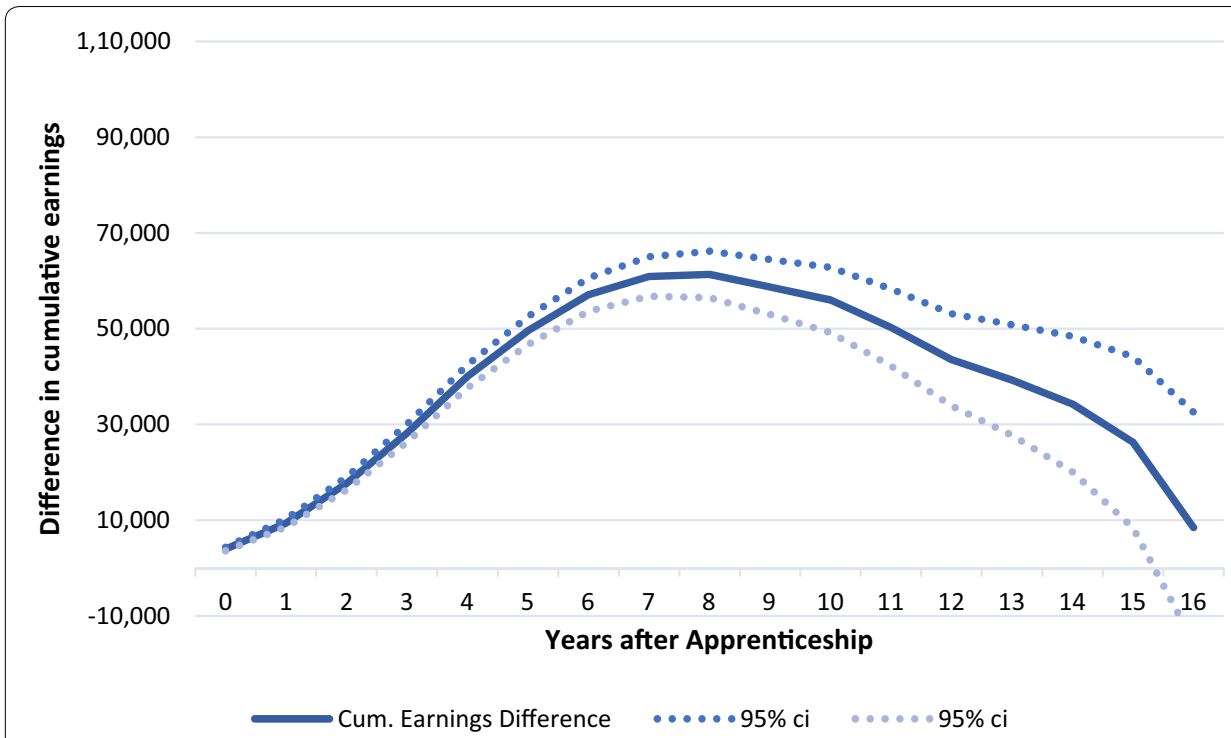

Fig. 6 Differences in cumulative earnings between foremen and academics after completed apprenticeship before matching (2213 foremen and 17,062 academics)

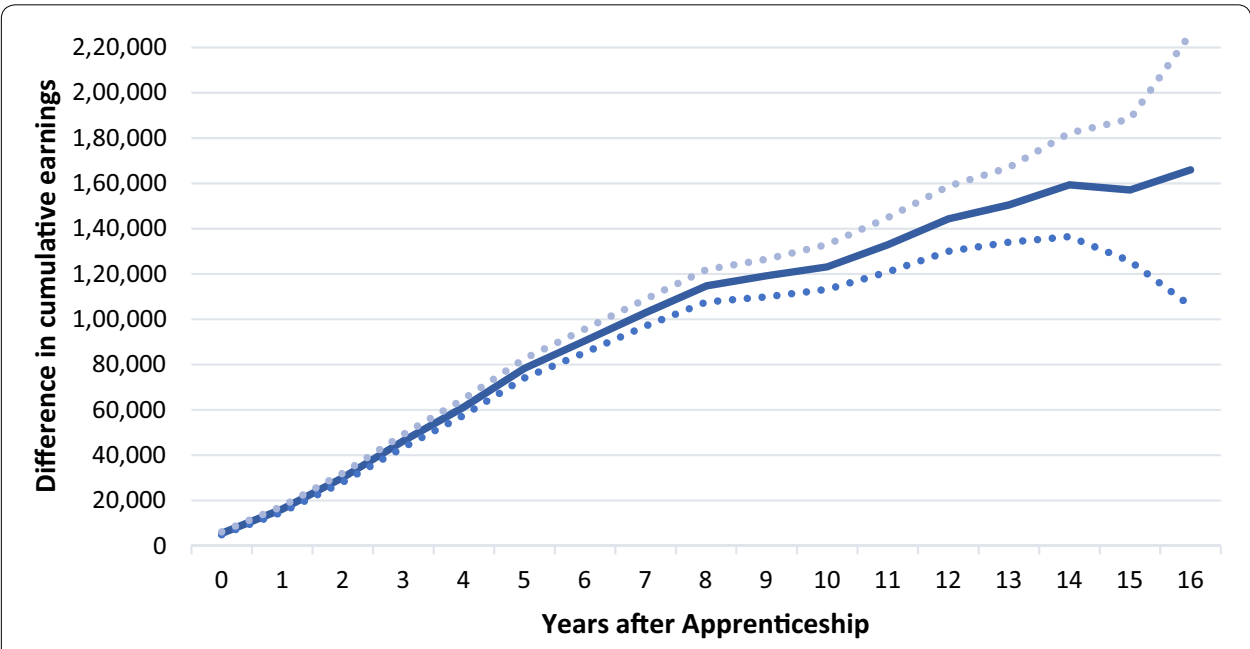

Cum. Earnings Difference ....995\% ci …995\% ci

Fig. 7 Differences in cumulative earnings between matched foremen and university academics $(N=732)$ 
$2,20,000$

品 $2,00,000$

产 $1,80,000$

ฮ $1,60,000$

.

1,40,000

כ $1,20,000$

亏 $1,00,000$

$. \subseteq \quad 80,000$

$\begin{array}{ll}\stackrel{\Xi}{\circlearrowright} & 80,000 \\ \text { d } & 60,000\end{array}$

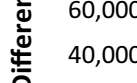

20,000

0

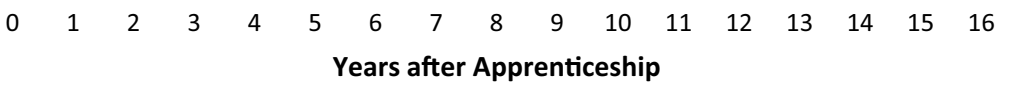

Cum. Earnings Difference .....95\% ci $\quad \ldots . .99 \%$ ci

Fig. 8 Differences in cumulative earnings between matched foremen and polytechnic academics $(N=1365)$

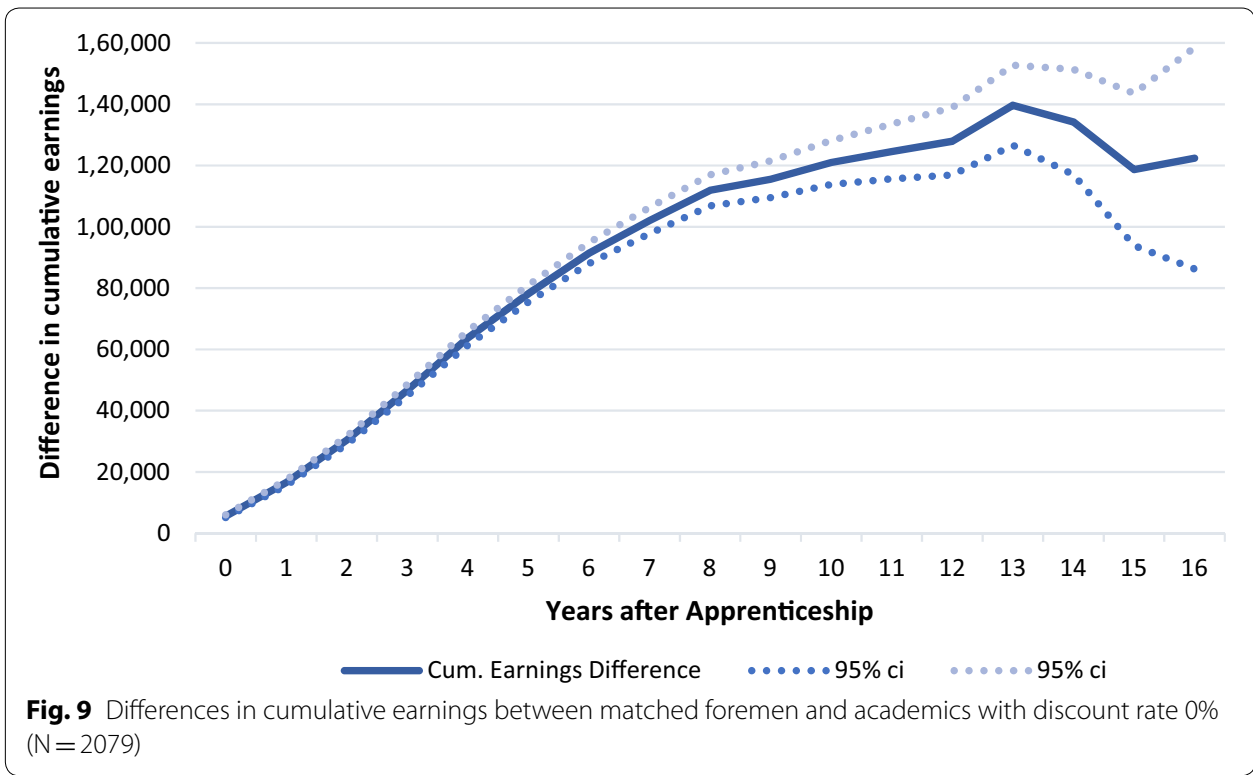




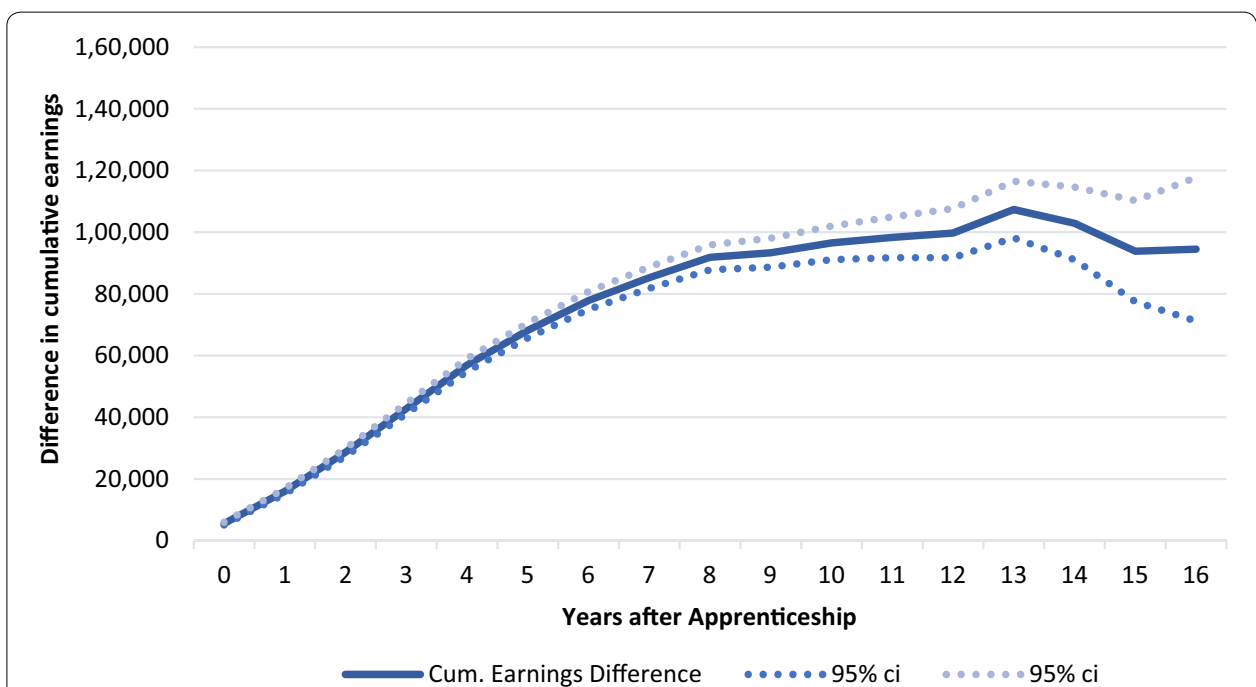

Fig. 10 Differences in cumulative earnings between matched foremen and academics with discount rate $5 \%$ $(N=2079)$

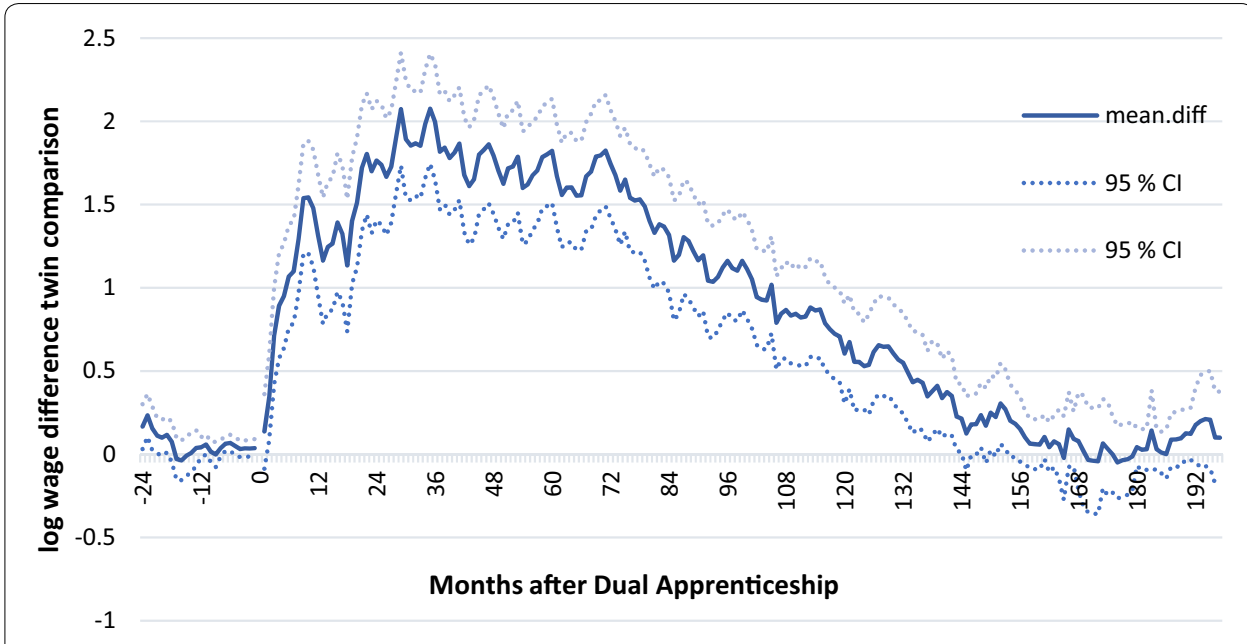

Fig. 11 Earnings differences between alternative comparison groups (181 foremen and 350 academics) 
Received: 2 December 2019 Accepted: 10 November 2020

Published online: 16 November 2020

\section{References}

Acemoglu D, Pischke S (2000) Certification of training and training outcomes. Eur Econ Rev 44:917-927

Adda J, Dustmann C, Meghir C, Robin J-M (2013) Career progression, economic downturns, and skills. NBER Working Paper 18832, Cambridge, MA

Alda H, Bender S, Gartner H (2005) The linked employer-employee dataset created from the IAB Establishment Panel and the process-produced data of the IAB (LIAB). Schmollers Jahrbuch 125:327-336

Bildungsberichterstattung A (2018) Bildung in Deutschland. wbv, Bielefeld

BMBF (2019) Aufstiegs-BAföG. Das Aufstiegsförderungsgesetz, Berlin

Bennett R, Glennerster H, Nevison D (1995) Investing in skill: expected returns to vocational studies. Educ Econ 3:99-117

Bhuller M, Mogstad M, Salvanes K (2017) Life-cycle earnings, education premiums, and internal rates of return. J Labor Econ 35:993-1030

BIBB (2016) Datenreport zum Berufsbildungsbericht 2016: Informationen und Analysen zur Entwicklung der beruflichen Bildung. Bundesinstitut für Berufsbildung, Bonn

Biewen M, Fitzenberger B, Osikominu A, Paul M (2014) The effectiveness of public sponsored training revisited: the importance of data and methodological choices. J Labor Econ 32:837-897

Bishop J, Mane F (2004) The impacts of career-technical education on high school labour market success. Econ Educ Rev 23:381-402

Blundell R, Dearden L, Goodman A, Reed H (2000) The returns to higher education in Britain: evidence from a British cohort. Econ J 110:F82-F99

Blundell R, Dearden L, Sianesi B (2005) Evaluating the effect of education on earnings: models, methods and results from the National Child Development Survey. J R Stat Soc Ser A 168:473-512

Böckerman P, Haapanen M, Jepsen C (2018) More skilled, better paid: labour-market returns to postsecondary vocational education. Oxf Econ Pap 70:485-508

Brunello G, Rocco L (2017) The labor market effects of academic and vocational education over the life cycle: evidence based on a British cohort. J Hum Cap 11:106-166

Brunello G, Weber G, Weiss CT (2017) Books are forever: early life conditions, education and lifetime earnings in Europe. Econ J 127:271-296

Büchel F, Helberger C (1995) Bildungsnachfrage als Versicherungsstrategie: der Effekt eines zusätzlich erworbenen Lehrabschlusses auf die beruflichen Startchancen von Hochschulabsolventen. Mitteilungen aus der Arbeitsmarkt- und Berufsforschung 28:32-43

Caliendo M, Kopeinig S (2008) Some practical guidance for the implementation of propensity score matching. J Econ Surv 22:31-72

Card D (1999) The causal effect of education on earnings. In: Ashenfelter O, Card D (eds) Handbook of labor economics, vol 3. North Holland, Amsterdam, pp 1801-1836

Cook TD, Shadish WR, Wong VC (2008) Three conditions under which experiments and observational studies produce comparable causal estimates: new findings from within study comparisons. J Policy Anal Manag 27:724-750

Cörvers F, Heijke H, Kriechel B, Pfeifer H (2011) High and steady or low and rising? Life-cycle earnings patterns in vocational and general education. ROA-RM-2011/7, Maastricht University

Dearden L, Mclntosh S, Myck M, Vignoles A (2002) The returns to academic and vocational qualifications in Britain. Bull Econ Res 54:249-274

Dehejia R, Wahba S (1999) Causal effects in nonexperimental studies: re-evaluating the evaluation of training programs. J Am Stat Assoc 94:1053-1062

Dehejia R, Wahba S (2002) Propensity score-matching methods for nonexperimental causal studies. Rev Econ Stat 84:151-161

Dellas H, Sakellaris P (2003) On the cyclicality of schooling: theory and evidence. Oxf Econ Pap 55:148-172

DIHK (2018) Aus- und Weiterbildung in Zahlen, Berlin

Eichhorst W, Rodríguez-Planas N, Schmidl R, Zimmermann K (2015) A road map to vocational education and training in industrialized countries. Ind Labor Relat Rev 68:314-337

Fersterer J, Pischke J-S, Winter-Ebmer R (2008) Returns to apprenticeship training in Austria: evidence from failed firms. Scand J Econ 110:733-753

Fitzenberger B, Osikominu A, Völter R (2005) Imputation rules to improve the education variable in the IAB employment subsample. Schmollers Jahrbuch 126:405-436

Flake R, Werner D, Zibrowius M (2016) Karrierefaktor berufliche Fortbildung_Einkommensperspektiven von Fortbildungsabsolventen. IW Trends 1, Bonn

Gartner H (2005) The imputation of wages above the contribution limit with the German IAB Employment Sample. FDZ Methodenreport 02/2005, Nürnberg

Golsteyn B, Stenberg A (2017) Earnings over the life course: general versus vocational education. J Hum Cap 11:167-212

Hall C (2016) Does more general education reduce the risk of future unemployment? Evidence from an expansion of vocational upper secondary education. Econ Educ Rev 52:251-271

Hanushek EA, Schwerdt G, Woessmann L, Zhang L (2017) General education, vocational education, and labor-market outcomes over the lifecycle. J Hum Resour 52:48-87

Heckman JJ, Ichimura H, Todd P (1998) Matching as an econometric evaluation estimator. Rev Econ Stud 65:261-294 
Heckman JJ, LaLonde R, Smith J (1999) The economics and econometrics of active labor market programs. In: Ashenfelter O, Card D (eds) Handbook of labor economics, vol 3. North Holland, Amsterdam, pp 1865-2097

Heckman J, Stixrud J, Urzua S (2006) The effects of cognitive and noncognitive abilities on labor market outcomes and social behavior. J Labor Econ 24:411-482

Heckman J, Humphries J, Veramendi G (2018) Returns to education: the causal effect of education on earnings, health and smoking. J Polit Econ 126:197-246

Jacobebbinghaus P, Alda H (2007) LIAB-Datenhandbuch: version 2.0. Institute for Employment Research, Nuremberg Kahn L (2013) Asymmetric information between employers. Am Econ J Appl Econ 5:165-205

Krueger D, Kumar K (2004) Skill-specific rather than general education: a reason for US-Europe growth differences? J Econ Growth 9:167-207

Lechner M (2002) Program heterogeneity and propensity score matching: an application to the evaluation of active labor market policies. Rev Econ Stat 84:205-220

Lewin K, Minks K-H, Unde S (1996) Abitur-Berufsausbildung-Studium: Zur Strategie der Doppelqualifizierung von Abiturienten. Mitteilungen aus der Arbeitsmarkt- und Berufsforschung 29:431-454

Malamud O, Pop-Eleches C (2010) General education versus vocational training: evidence from an economy in transition. Rev Econ Stat 92:43-60

Meer J (2007) Evidence on the returns to secondary vocational education. Econ Educ Rev 26:559-573

Mohrenweiser J, Wydra-Somaggio G, ZwickT (2020) Information advantages of training employers despite credible training certificates. Oxf Econ Pap 72:651-671

Mueser P, Troske K, Goriaslavsky A (2007) Using state administrative data to measure program performance. Rev Econ Stat 89:761-783

OECD (2008) Education at a glance. Paris

OECD (2015) ISCED 2011 operational manual-guidelines for classifying national education programmes and related qualifications. OECD Publishing, Paris

Pischke J-S, von Wachter T (2008) Zero Returns to compulsory schooling in Germany: evidence and interpretation. Rev Econ Stat 90:592-598

Pohl S, Steiner P, Eisermann J, Soellner R, Cook T (2009) Unbiased causal inference from an observational study: results of a within-study comparison. Educ Eval Policy Anal 31:463-479

Reyes L, Rodríguez J, Urzúa S (2016) Heterogeneous economic returns to postsecondary degrees: evidence from Chile. J Hum Resour 51:416-460

Rosenbaum P, Rubin D (1983) The central role of the propensity score in observational studies for causal effects. Biometrika $70: 41-55$

Rosenbaum P, Rubin D (1985) Constructing a control group using multivariate matched sampling methods that incorporate the propensity score. Am Stat 39:33-38

Rubin D (1973) Matching to remove bias in observational studies. Biometrics 29:159-184

Ryan P (2001) The school-to-work transition: a cross-national perspective. J Econ Lit 39:34-92

Rzepka S (2018) Labor market returns to college education with vocational qualifications. Educ Econ 26:411-431

Schönberg U (2007) Testing for asymmetric employer learning. J Labor Econ 25:651-692

Shadish WR, Clark MH, Steiner P (2008) Can nonrandomized experiments yield accurate answers? A randomized experiment comparing random to nonrandom assignment. J Am Stat Assoc 103:1334-1344

Smith J, Todd P (2005) Does matching overcome LaLonde's critique of non-experimental estimators? J Econom 125:305-353

Soskice D (1994) Reconciling markets and institutions: the German apprenticeship system. In: Lynch LM (ed) Training and the private sector: international comparisons. University of Chicago Press, Chicago, pp 26-60

Stenberg A, Westerlund O (2015) The long-term earnings consequences of general vs. specific training of the unemployed. IZA J Eur Labor Stud 4:22

Stuart E (2010) Matching methods for causal inference: a review and a look forward. Stat Sci Rev J Inst Math Stat 25:1

Tuor S, Backes-Gellner U (2010) Risk-return trade-offs to complete educational paths: vocational, academic and mixed. Int J Manpow 31:495-519

Verhaest D, Baert S (2018) The effects of workplace learning in higher education on employment and match quality: is there an early-career trade-off? Empir Econ 55:1229-1270

von Wachter T, Bender S (2006) In the right place at the wrong time: the role of firms and luck in Young Workers' careers. Am Econ Rev 96:1679-1705

Winkelmann R (1996) Employment prospects and skill acquisition of apprenticeship-trained workers in Germany. Ind Labor Relat Rev 49:658-672

Wolter S, Ryan P (2011) Apprenticeship. Handb Econ Educ 3:521-576

Wolter A, Banscherus U, Kamm C, Otto A, Spexard A (2014) Durchlässigkeit zwischen beruflicher und akademischer Bildung als mehrstufiges Konzept: Bilanz und Perspektiven. Beiträge zur Hochschulforschung 36:8-39

Zilic I (2018) General versus vocational education: lessons from a quasi-experiment in Croatia. Econ Educ Rev 62:1-11

\section{Publisher's Note}

Springer Nature remains neutral with regard to jurisdictional claims in published maps and institutional affiliations. 